\title{
Thermogravimetric Analysis and Global Kinetics of Segregated MSW Pyrolysis
}

\author{
Dwi Aries Himawanto \\ Department of Mechanical Engineering, Sebelas Maret University \\ Jalan Ir. Sutami no. 36A, Kentingan, Surakarta, Republic of Indonesia \\ Ph.D student in Department of Mechanical and Industrial Engineering, Gadjah Mada University \\ Tel: 62-271-632163 E-mail: dwi_ah@uns.ac.id \\ Indarto, Harwin Saptoadi \& Tri Agung Rohmat \\ Department of Mechanical and Industrial Engineering, Gadjah Mada University \\ Jalan Grafika no. 2 Bulaksumur, Yogyakarta, Republic of Indonesia
}

Received: October 26, $2011 \quad$ Accepted: November 28, $2011 \quad$ Published: January 1, 2012

doi:10.5539/mas.v6n1p120 URL: http://dx.doi.org/10.5539/mas.v6n1p120

The research is financed by the Directorate General of Higher Education, Ministry of National Education RoI under Disertasion Research Grant in 2010 and Competitive Research Grant in 2009-2010 research program

\begin{abstract}
Municipal Solid Wastes (MSW) has great potential as a clean, renewable feedstock for producing modern energy carriers through thermochemical process, called pyrolysis. However, despite their enormous potential as energy sources, their thermal characteristics are still not well known. Moreover many researches just pay a little attention on MSW from developing countries, for example Indonesia MSW contains some indigenous wastes such as bamboo and banana leaves wastes, therefore this paper tries to show the slow pyrolysis characteristics of Indonesian MSW.

Investigations on behaviors of segregated MSW slow pyrolysis have been conducted using macro balance apparatus. Four components of segregated MSW (bamboo wastes, banana leaves wastes, snack wrap wastes and styrofoam wastes) and their blends were pyrolised and then thermogravimetry analysis has been done and their characteristics such as pyrolysis profiles and activation energies, were analysed and calculated. About 20 grams of samples were pyrolysed under $100 \mathrm{ml} / \mathrm{min} \mathrm{N}_{2}$ at constant heating rate of $10{ }^{\circ} \mathrm{C} / \mathrm{min}$ from room temperature to $400{ }^{\circ} \mathrm{C}$ final pyrolysis temperature and then the temperature of samples were kept constant for 30 minutes. The nitrogen flow serve swept gas which ensures an inert atmosphere during the pyrolysis test. In order to indentify pyrolysis characteristics of the samples, thermogravimetry analysis was performed. The recorded data were weight losses and sample temperatures during the pyrolisis process.

The results of the research showed that bamboo wastes and banana leaves wastes could be categorized as low stability organics, while snack wrap wastes could be categorized as polymer mixture materials and styrofoam wastes could be classified as plastic materials. Meanwhile profiles of blends materials pyrolysis followed the characteristics of their single components which is indicated by peak temperature. This study also found that global kinetic method could calculate the pyrolysis activation energy.
\end{abstract}

Keywords: MSW, Pyrolysis, Thermogravimetry, Global kinetics

\section{Introduction}

Municipal Solid Waste (MSW) management become important because of public awareness towards cleaner environment, due to the increase of their quantities and complex components. In Indonesia, the annual MSW production in 2008 were 36.5 billion tons which consists of $58 \%$ organic wastes, $14 \%$ plastic based wastes, 9\% paper based wastes and wood based wastes. The limitations and impact of existing MSW treatments technology forced researchers to develop alternative waste treatments technology and the one alternative is to convert MSW to energy. On the other side, the depletion of fossil fuel reserves and the increasing of energy need makes researches about alternative energy sources with abundant reserves more important. 
Slow pyrolysis of MSW can be a prospective technology to treat MSW if compared with other alternatives which can solve environmental and energy problems. Pyrolisis is defined as thermal degradation of solids in a limited oxygen condition that can produce permanent gas, pyrolitic liquid and char (Di Blasi, 2008). A research of the MSW pyrolisis using $12 \mathrm{~kg} \mathrm{MSW}$ with a temperature range $400{ }^{\circ} \mathrm{C}-650{ }^{\circ} \mathrm{C}$ for 4 hours could produce $52.2 \%$ tar, 25.2\% char and 22.6\% gas (Ojolo and Bamgboye, 2005). A study about segregated MSW slow pyrolisis in a packed bed pyrolizer showed that packed bed pyrolisis system could increase char production 30\% - 100\% compared with the TGA processes (Swithenbank, et al., 2005). A research which carbonized MSW as an artificial coal showed that the heating value of MSW char could reach a half of coal heating value (Matsuzawa, et al., 2007). An optimum slow pyrolysis condition which could produce the balance pyrolisis product was conducted by Phan et al. (2008) and found the optimum pyrolysis temperature should be below $500{ }^{\circ} \mathrm{C}$. Grammelis et al. (2009) conducted a reserach about pyrolysis kinetics and combustion characteristics of waste recovered fuels, and found that the thermal degradation of the refuse derived fuel samples was modeled assuming four parallel reactions corresponding to the devolatilisation of cellulose, hemicellulose, lignin and plastics.

Moreover many researches pay only a little attention on MSW from developing countries, for example Indonesia MSW contains some indigenous wastes such as bamboo and banana leaves wastes, therefore this paper tries to show the slow pyrolysis characteristics of Indonesian MSW.

\section{Materials and Methods}

\subsection{Samples}

Materials tested in this research were unprocessed MSW components which were taken from Final Waste Diposal Site Piyungan Yogyakarta, and consist of organic wastes and unorganic wastes, which could be seen on Figure 1.

The organic wastes consists of bamboo wastes (from Javanese traditional basket) and banana leaves wastes (from Javanese traditional food wrap). These wastes come from Indonesian traditional market. The anorganic wastes, especially plastic based wastes, consists of snack wrap wastes and styrofoam wastes. All of samples were crushed until the particles sizes of samples passed 20 mesh.

\subsection{Methods}

Pyrolysis was carried out with macro balance which was adopted from Swithenbank et al. (2005). About 20 grams of sample was pyrolysed under $100 \mathrm{ml} / \mathrm{min}_{2}$ at constant heating rate of $10{ }^{\circ} \mathrm{C} / \mathrm{min}$ from room temperature to $400{ }^{\circ} \mathrm{C}$ final pyrolysis temperature which is kept constant for 30 minutes. The nitrogen flow serve swept gas which ensures an inert atmosphere during the pyrolysis test.

In order to indentify pyrolysis characteristics of the samples, thermogravimetry analysis was performed. The recorded datas were weight losses and sample temperatures during the pyrolisis process. A K-type thermocouple was inserted into the sample which located $2 \mathrm{~cm}$ from the center of sample basket and $1 \mathrm{~cm}$ above the base of sample basket. The sample temperatures were recorded with ADAM 4018 data acquisitions system, while the weight losses recorded with A\&D GF-300 Digital Scale. The scheme of experimental apparatus is described in Figure 2.

\section{Results and Discusion}

\subsection{Single Component Pyrolysis}

Pyrolysis temperature ranges of each samples could be seen on Table 1, the table shows that bamboo was pyrolised starting from around $241.6^{\circ} \mathrm{C}$ and continuing until $410{ }^{\circ} \mathrm{C}$, where the highest mass loss occured at about $277.9{ }^{\circ} \mathrm{C}$, while the banana leaves wastes was pyrolysed from $199^{\circ} \mathrm{C}$ to $414.7^{\circ} \mathrm{C}$ with the highest decomposistion rate at $321.8^{\circ} \mathrm{C}$. Snack wrap wastes were thermally degraded at temperatures between $262.5^{\circ} \mathrm{C}$ and $410{ }^{\circ} \mathrm{C}$ with the highest mass losses occured at $362.5^{\circ} \mathrm{C}$. Styrofoam wastes were pyrolised at $316.3{ }^{\circ} \mathrm{C}-417{ }^{\circ} \mathrm{C}$ with two peak temperatures which occured at $370.6^{\circ} \mathrm{C}$ and $407.5^{\circ} \mathrm{C}$. From the experimental results, it could be concluded that bamboo wastes was starting pyrolised at of hemicelullose decomposition temperature. Heikkinen et al. (2004) explained that the maximum decomposition rates of xylan, the one of hemicelulose type, occured at $298{ }^{\circ} \mathrm{C}$. The same results also occured on banana leaves wastes pyrolysis. Based on the peak temperature, i.e. the temperature which highest devolatilisastion rates occured which defined by Heikkinen et al. (2004), bamboo wastes and banana leaves wastes catagorised as low stability organic component (LSOC), i.e. materials which have the peak temperature around $300{ }^{\circ} \mathrm{C}$. The peak temperature of snack wrap wastes occured at $362.5^{\circ} \mathrm{C}$, which is close to the peak temperature of milk carton (Heikkinen et al. (2004)), i.e. $368^{\circ} \mathrm{C}$, although the main material of snack wrap wastes is polypropylene which has peak temperature around $472{ }^{\circ} \mathrm{C}$. This result gave prediction that snack wrap 
wastes were laminated materials which consisted of several materials and one of those material had the lower peak temperature than polypropylene. Styrofoam wastes pyrolisis had two peak temperatures, i.e. $370.6{ }^{\circ} \mathrm{C}$ and $407.5{ }^{\circ} \mathrm{C}$ which could be categorised as plastic materials which have high thermal stability and have peak temperature above of $400{ }^{\circ} \mathrm{C}$. The styrofoam wastes pyrolysis which is used in this research followed the thermal decomposition of GS and polystyrene, which have peak temperature $394{ }^{\circ} \mathrm{C}$ and $467{ }^{\circ} \mathrm{C}$. GS is the real plastic wastes from Germany and the exact composition is unknown (Heikkinen, et al., 2004).

\subsection{Pyrolysis of Blends Materials}

Table 2 shows the pyrolysis temperature ranges and the peak temperature of mixed components samples. It coud be seen that the mixed component samples initial pyrolysis temperature located between the initial pyrolysis temperature of each component with exception in organic mixed component.

The initial pyrolysis temperature of organic mixed component higher than the single component pyrolysis initial temperature. It caused of synergethic reactions which occured between the component.

Banana wastes - bamboo wastes mixed samples begin to decompose at $176.3{ }^{\circ} \mathrm{C}$ and finished at $418.8{ }^{\circ} \mathrm{C}$ and signed with one maximum mass loss rate at $322.7^{\circ} \mathrm{C}$ and one shoulder located at $273.4^{\circ} \mathrm{C}$. According to Di Blasi (2008) biomass started to be decomped at $227^{\circ} \mathrm{C}$, while Kalita et al. (2009) found that bamboo dust pyrolysed at $190^{\circ} \mathrm{C}$ to $365^{\circ} \mathrm{C}$. Shoulder which located at left side of maximum loss rate temperature indicated that the sample was lignocellusic material which maximum mass loss rate just occured at one sample while the other sample would be signed with litle peak (shoulder). Snack wrapping - styrofoam mixed wastes pyrolysis occured at $284.4{ }^{\circ} \mathrm{C}-$ $396.8^{\circ} \mathrm{C}$ with two maximum mass losses temperature.

Meanwhile for the unorganic-organic blends gave the same results i.e there were some peak which represented their main component as seen in Figure 3 -Figure 6. From those figures, could be seen that bamboo wastes - snack wrap wastes mixtures started pyrolise at $183.3{ }^{\circ} \mathrm{C}$ and continuing until $416.3^{\circ} \mathrm{C}$ with three peak temperatures which occured at $276.5^{\circ} \mathrm{C}, 316.3^{\circ} \mathrm{C}$ and $394.3^{\circ} \mathrm{C}$. The first peak temperature refered to bamboo peak temperature, the third peak temperature near to the snack wrap temperature, while the second peak temperature occured as the effect of synergethic reactions between the components. The phenomena could be seen in banana wastes - snack wrap wastes mixtures.

A different phenomena could be seen in the styrofoam based mixtures pyrolysis. It could be observed that the first peak temperature, which represented biomass component temperature, were lower than its component peak temperatures. These conditions predicted caused of the styrofoam physical characterstics i.e melt and hardened while pyrolised.

\subsection{Global Kinetic Analysis}

Energy activation is calculated based on Arrhenius formulae with first reaction order, which called global kinetics, and expressed as the following formulae

$$
\frac{d x}{d t}=A e^{-\frac{E}{R T}}(1-x)
$$

where $\mathrm{A}$ is pre-exponential factor, $\mathrm{E}$ is activation energy, $\mathrm{T}$ is temperature, $\mathrm{t}$ is time, $\mathrm{x}$ is pyrolysis conversion which calculated as

$$
x=\frac{w_{0}-w}{w_{0}-w_{f}}
$$

if $\beta$ is a constant heating rate which defined as

$$
\beta=\frac{d T}{d t}
$$

Rearranging equation (1) gives

$$
\begin{gathered}
\frac{d x}{d T}=\frac{A}{\beta} e^{-\frac{E}{R T}}(1-x) \\
\frac{d x}{(1-x)}=\frac{A}{\beta} e^{-\frac{E}{R T}} d T
\end{gathered}
$$


Integrating equation (5), the following equation can be obtained

$$
-\ln (1-x)=\frac{A}{\beta} \int e^{-\frac{E}{R T} d T}
$$

Since $\int e^{-\frac{E}{R T} d T}$ has no exact integral, $\int e^{-\frac{E}{R T} d T}$ can be expressed as an asymptotic series and integrated, with the higher order terms ignored, and equation (6) becomes

$$
-\ln (1-x)=\frac{A R T^{2}}{\beta E}\left[1-\frac{2 R T}{E}\right] e^{-\frac{E}{R T}}
$$

Rearranging equation (7) gives the following equation

$$
-\frac{\ln (1-x)}{T^{2}}=\frac{A R}{\beta E}\left[1-\frac{2 R T}{E}\right] e^{-\frac{E}{R T}}
$$

Expressing equation (8) into logarithmic form gives

$$
\ln \left[-\frac{\ln (1-x)}{T^{2}}\right]=\ln \left[\frac{A R}{\beta E}\left[1-\frac{2 R T}{E}\right]\right]-\frac{E}{R T}
$$

Since $\frac{2 R T}{E}<<1$ is assumed,

$$
\ln \left[-\frac{\ln (1-x)}{T^{2}}\right]=\ln \left[\frac{A R}{\beta E}\right]-\frac{E}{R T}
$$

And by make a plot the relation between $\ln \left[-\frac{\ln (1-x)}{T^{2}}\right]$ and $1 / \mathrm{T}$, give straight line with $-\mathrm{E} / \mathrm{R}$ slope thus the activation energy can be defined, and by taking the temperature at which $\mathrm{W}_{\mathrm{t}}=\left(\mathrm{W}_{\mathrm{o}}+\mathrm{W}_{\mathrm{f}}\right) / 2$ in the place of $\mathrm{T}$ in the intercept term of Eq. (10), the pre-exponential factor A can also be determined.

Figure 7 - Figure 13 displayed the plot between $\ln \left[-\frac{\ln (1-x)}{T^{2}}\right]$ and $1 / T$ for the samples both singles and mixed, and the results of all samples summarized in Tables 3 .

The results showed that bamboo pyrolysis activation energy is $52.598 \mathrm{~kJ} / \mathrm{mol}$, the previous study about $b a m b o o$ dust pyrolysis had been done by Kalita et al. (2009) and found that the pyrolysis activation energy was 98.22 $\mathrm{kJ} / \mathrm{mol}$ with reaction order 3.55 at temperature range $190{ }^{\circ} \mathrm{C}-365^{\circ} \mathrm{C}$. Meanwhile PS and LDPE had activation energy were $251.2 \mathrm{~kJ} / \mathrm{mol}$ and $206.4 \mathrm{~kJ} / \mathrm{mol}$ (Sørum (2001)), while the activation energy of styrofoam wastes and snack wrap wastes which found from this study were $118.208 \mathrm{~kJ} / \mathrm{mol}$ and $124.186 \mathrm{~kJ} / \mathrm{mol}$. From this study also found the pyrolysis activation energy of banana leaves was $49.063 \mathrm{~kJ} / \mathrm{mol}$.

For biomass based materials, the pyrolysis activation energy influenced by thermal decomposition process of their main component i.e hemicelulose, lignin and cellulose. Hemicelulose decomposed at tamperature range $225{ }^{\circ} \mathrm{C}-325{ }^{\circ} \mathrm{C}$ with activation energy varied between $80-116 \mathrm{~kJ} / \mathrm{mol}$, lignin pyrolysed at $325^{\circ} \mathrm{C}-375{ }^{\circ} \mathrm{C}$ and have higher activation energy $195-286 \mathrm{~kJ} / \mathrm{mol}$, while cellulose thermally decomposed gradually at $250{ }^{\circ} \mathrm{C}$ $-500{ }^{\circ} \mathrm{C}$ and had the lowest activation energy $18-65 \mathrm{~kJ} / \mathrm{mol}$ (Di Blasi, 2008).

Meanwhile blend materials pyrolysis activation energy values gave several results. The lignocellulosic blends samples pyrolysis gave the lower activation energy if compared with their component, it caused of the synergistic effect which occured at overlapping pyrolysis temperatures. Unorganic wastes blends pyrolysis also 
occured at the lower activation energy than their components. These phenomenon is predicted caused by the efect of styrofoam component which have nearly $100 \%$ of volatile matter. The greater volatile components in styrofoam wastes make the pyrolysis process could done with lower activation energy, these occured in styrofoam wastes based blends.

On the contrary, the snack wrap wastes based blends need a higher activation energy if it is compared their lignocellulosic component and if compared with styrofoam based blend pyrolysis, these different behaviour can be explained by the fact that polypropylene soften at about $440{ }^{\circ} \mathrm{C}$ (Cai, et al., 2008) which could be inhibit the volatile matter evolution of lignocellulosic component so that to increase the activation energy.

\section{Conclusions}

The results of this research showed that the organic components wastes could be catogorized as low stability organics, while the snack wrapping could be categorised as mixed polymer material. Styrofoam wastes could be categorised as plastic material which have high thermal stablity. This study also found that global kinetic method could to calculate the pyrolysis activation energy. The lignocellulosic blends pyrolysis gave the lower activation energy if compared with their component. Anorganic wastes blends pyrolysis also occured at the lower activation energy than their components. On the contrary, the snack wrap wastes based blends need the higher activation energy if compared their lignocellulosic component and if compared with styrofoam based blend pyrolysis.

\section{References}

Cai, J., Wang, Y., Zhou, L., \& Huang, Q. (2008). Thermogravimetric Analysis and Kinetic of Coal/Plastic Blends during Co-Pyrolisis in Nitrogen Atmosphere. Fuel Processing Technology, 89, 21-27. http://dx.doi.org/10.1016/j.fuproc.2007.06.006

Di-Blasi, C. (2008). Modeling Chemical and Physical Processes of Wood and Biomass Pyrolisis. Progress in Energy and Combustion Science, 34, 47-99. http://dx.doi.org/10.1016/j.pecs.2006.12.001

Grammelis, P., Basinas, P., Malliopoulou, A., \& Sakellaropoulos, G. (2009). Pyrolisis Kinetics and Combustion Characteristics of Waste Recovered Fuels. Fuel, 88, 195-205. http://dx.doi.org/10.1016/j.fuel.2008.02.002

Heikkinen, J. M., Hordijk, J. C., de Jong, W., Spliethoff, H.(2004). Thermogravimetry as a tool to clasify waste components to be used for energy generation. J.Anal.Appl.Pyrolysis, 71, 883-900. http://dx.doi.org/10.1016/j.jaap.2003.12.001

Himawanto, D. A., Indarto, Saptoadi, H., \& Rohmat,T. A.(2011). Characteristics and Global Kinetics Approaches of Segregated MSW Slow Pyrolysis (in Indonesian languange). Jurnal Reaktor, 13(3), 140-147.

Kalita, P., Mohan, G., Pradeep, K., \& Mahanta, P. (2009). Determination and Comparasion of Kinetic Parameter of Low Density Biomass Fuels. Journals of Renewable and Sustainable Energy, 1, 023109. http://dx.doi.org/10.1063/1.3126936

Matsuzawa, Y., Mae, K., Hasegawa, I., Suzuki, K., Fujiyoshi, H., Ito, M., \& Ayabe, M. (2007). Characterization of Carbonized Municipal Waste as Substitute for Coal Fuel. Fuel, 86, 264-272. http://dx.doi.org/10.1016/j.fuel.2006.06.008

Ojolo, S. J., \& Bamgboye, A. I. (2005).Thermochemical Conversion of Municipal Solid Waste to Produce Fuel and Reduce Waste. Agicultural Engineering International: the CIGR Ejournal, Vol. VII, Manuscript EE 05006.

Phan, A. N., Ryu, C., Sharifi, V. N., \& Swithenbank, J. (2008). Characterisation of Slow Pyrolisis Products from Segregated Wastes for Energy Production. J.Anal.Appl.Pyrolisis, 81, 65-71. http://dx.doi.org/10.1016/j.jaap.2007.09.001

Sørum, L. (2001). Characteristics of MSW for Combustion System, Technical Report, SINTEF Energy Research.

Swithenbank, J., Sharifi, V. N., \& Ryu, C. (2005).Waste Pyrolisis and Generation of Storable Fuel. SUWIC Department of Chemical and Process Engineering, The University of Sheffield.

Yang, Y. B., Phan, A. N., Ryu, C., Sharifi, V., Swithenbank, J. (2007). Mathematical Modelling of Slow Pyrolisis of Segregated Solid Waste in A Packed-Bed Pyroliser. Fuel, 86, 169-180. http://dx.doi.org/10.1016/j.fuel.2006.07.012 
Table 1. Singles component samples pyrolysis temperature ranges

\begin{tabular}{lll}
\hline Sample & $\begin{array}{l}\text { Pyrolysis } \\
\text { Temperature } \\
\left({ }^{\circ} \mathrm{C}\right)\end{array}$ & $\begin{array}{l}\text { Peak Temperature } \\
\left({ }^{\circ} \mathrm{C}\right)\end{array}$ \\
\hline Bamboo wastes & $143.1-426.5$ & 277.9 \\
Banana leaves wastes & $130-414.7$ & 321.8 \\
Snack wrap wastes & $222.8-422.7$ & 362.5 \\
Styrofoam wastes & $316.3-417$ & $370.6 ; 407.5$ \\
\hline
\end{tabular}

Table 2. Mixed samples pyrolysis temperature ranges

\begin{tabular}{lll}
\hline Sample & $\begin{array}{l}\text { Pyrolysis } \\
\text { Temperature } \\
\left({ }^{\circ} \mathrm{C}\right)\end{array}$ & $\begin{array}{l}\text { Peak Temperature } \\
\left({ }^{\circ} \mathrm{C}\right)\end{array}$ \\
\hline $\begin{array}{l}50 \% \text { banana wastes }-50 \% \text { bamboo } \\
\text { wastes }\end{array}$ & $176.3-418.8$ & 322.7 \\
$\begin{array}{l}50 \% \text { snack wrap wastes- } 50 \% \\
\text { styrofoam wastes }\end{array}$ & $284.4-396.8$ & $390.9 ; 415$ \\
$\begin{array}{l}50 \% \text { bamboo wastes }-50 \% \text { snack } \\
\text { wrap wastes }\end{array}$ & $183.3-416.3$ & $276.5 ; 316.3 ; 394.3$ \\
$\begin{array}{l}50 \% \text { bamboo wastes }-50 \% \\
\text { styrofoam wastes }\end{array}$ & $143.3-462.3$ & $232.8 ; 357.0$ \\
$\begin{array}{l}50 \% \text { banana leaves wastes }-50 \% \\
\text { snack wrap wastes }\end{array}$ & $166.9-425.9$ & $312.1 ; 409.5$ \\
$\begin{array}{l}50 \% \text { banana leaves wastes }-50 \% \\
\text { styrofoam wastes }\end{array}$ & $173.7-405.0$ & $276.2 ; 338.1 ; 401.5$ \\
\hline
\end{tabular}

Table 3. Summary of kinetic parameters for samples pyrolysis

\begin{tabular}{llll}
\hline Samples & $\mathbf{E}$ & $\begin{array}{l}\mathbf{A} \\
(\mathbf{m} \mathbf{m} / \mathbf{m o l})\end{array}$ & $\mathbf{R}^{\mathbf{2}} \mathbf{)}$ \\
\hline Bamboo wastes & 52.598 & $3.00 \times 10^{7}$ & 0.9869 \\
Banana wastes & 49.063 & $2.79 \times 10^{7}$ & 0.9649 \\
Snack wrapping wastes & 124.186 & $8.36 \times 10^{7}$ & 0.9292 \\
Styrofoam wastes & 118.208 & $8.37 \times 10^{7}$ & 0.9776 \\
$50 \%$ banana leaves- 50 \% bamboo wastes & 35.014 & $1.97 \times 10^{7}$ & 0,9543 \\
$50 \%$ snack wrapping- 50 \% styrofoam wastes & 84.005 & $4.44 \times 10^{7}$ & 0.9715 \\
$50 \%$ bamboo wastes - 50 \% snack wrapping wastes & 78.04 & $4.87 \times 10^{7}$ & 0.9745 \\
$50 \%$ bamboo wastes - 50 \% styrofoam wastes & 33.46 & $1.59 \times 10^{7}$ & 0.9759 \\
$50 \%$ banana leaves wastes - 50 \% snack wrapping wastes & 65.615 & $4.00 \times 10^{7}$ & 0.9866 \\
$50 \%$ banana leaves wastes - 50 \% styrofoam wastes & 56.771 & $3.39 \times 10^{7}$ & 0.9769 \\
\hline
\end{tabular}




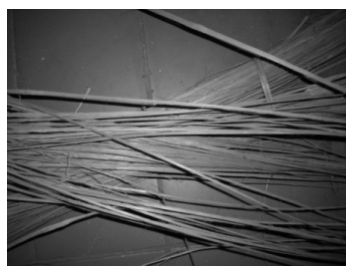

(a)

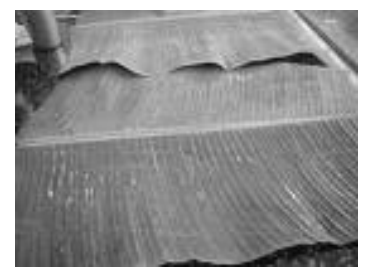

(b)

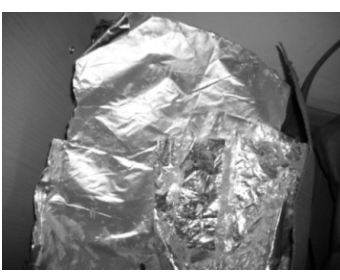

(c)

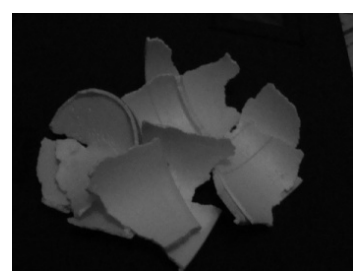

(d)

Figure 1. Materials

(a) Bamboo wastes; (b) Banana leaves wastes; (c) Snack wrap wastes; (d) Styrofoam wastes

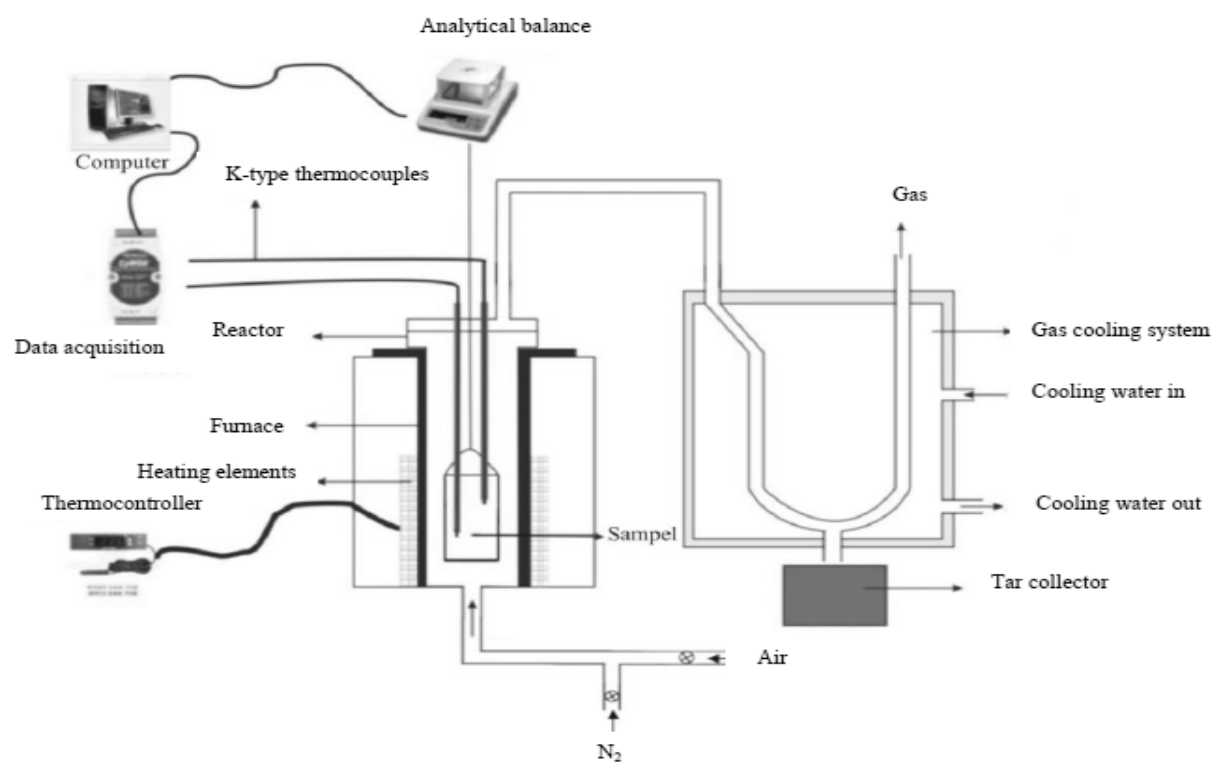

Figure 2. Experimental apparatus schematic

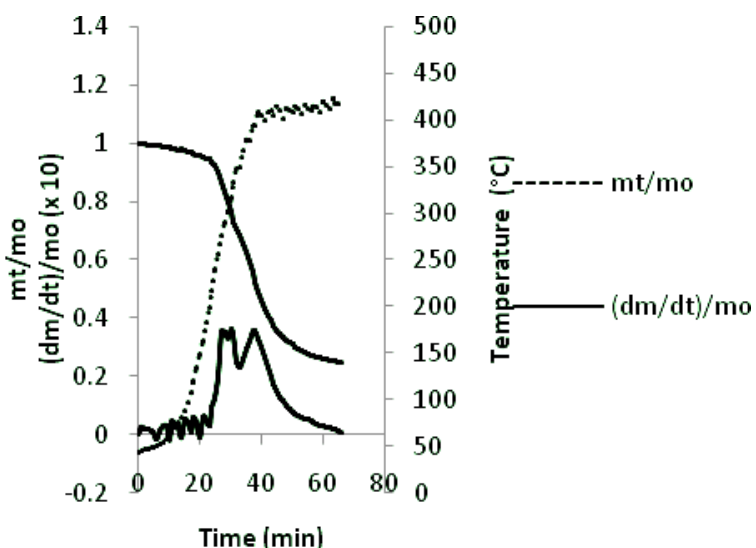

Figure 3. Bamboo - snack wrap wastes pyrolysis characteristics 


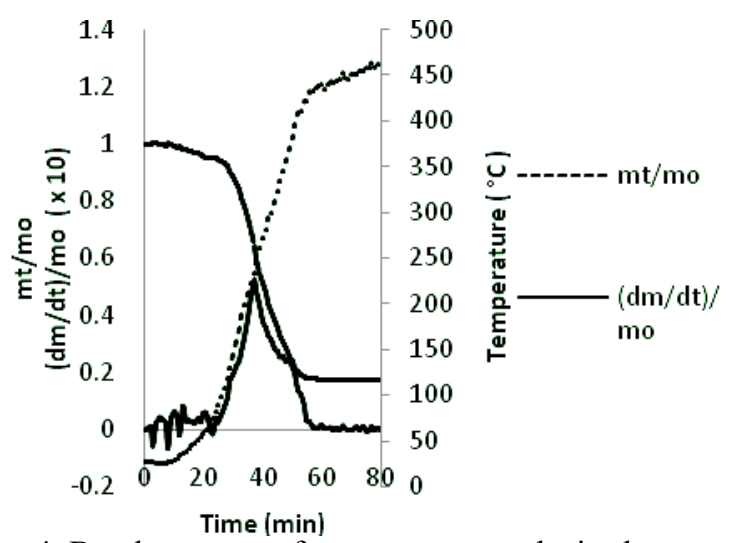

Figure 4. Bamboo - styrofoam wastes pyrolysis characteristics

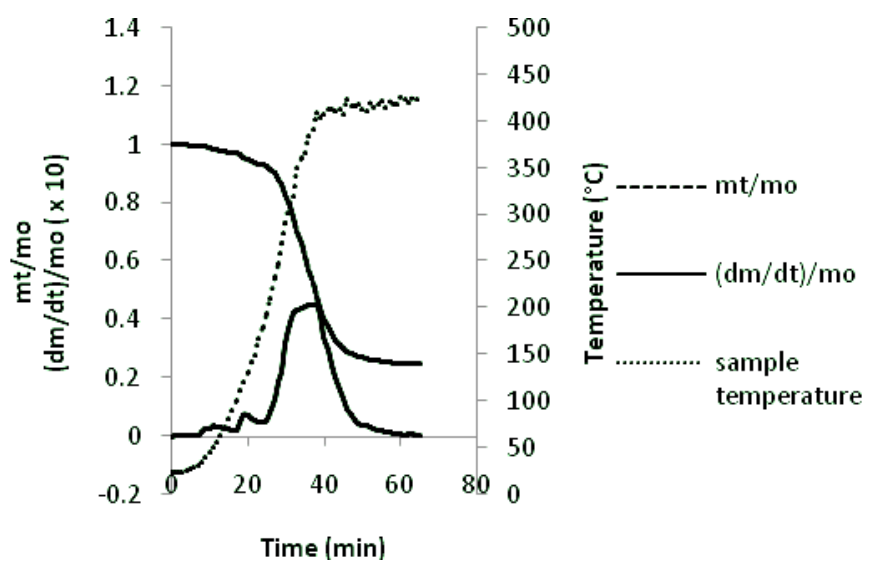

Figure 5. Banana leaves - snack wrap wastes pyrolysis characteristics

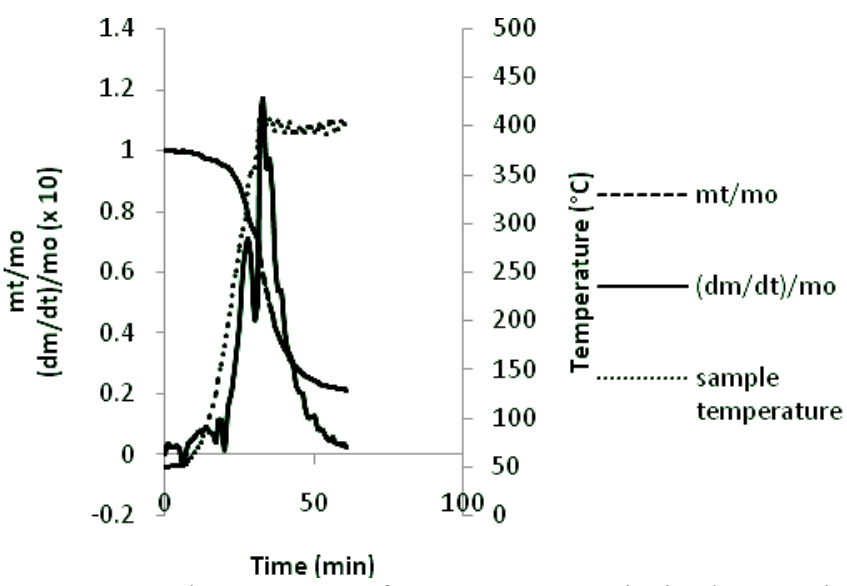

Figure 6. Banana leaves - styrofoam wastes pyrolysis characteristics 


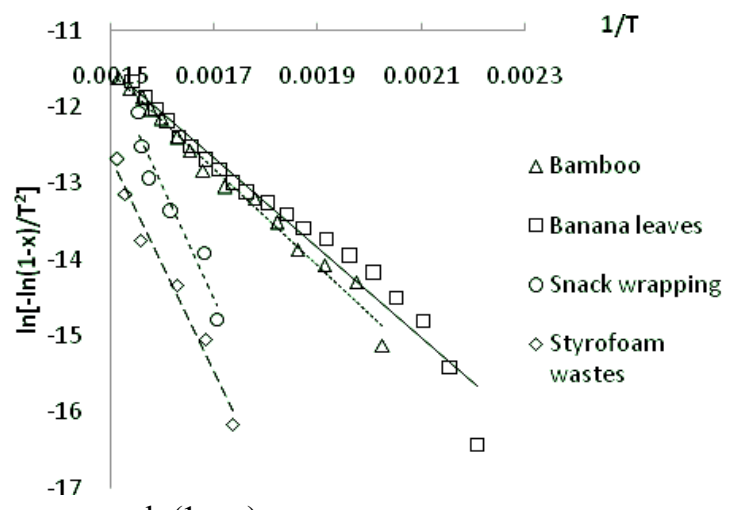

Figure 7. Plot of $\ln \left[-\frac{\ln (1-x)}{T^{2}}\right]$ vs $1 / T$ of single component samples pyrolysis

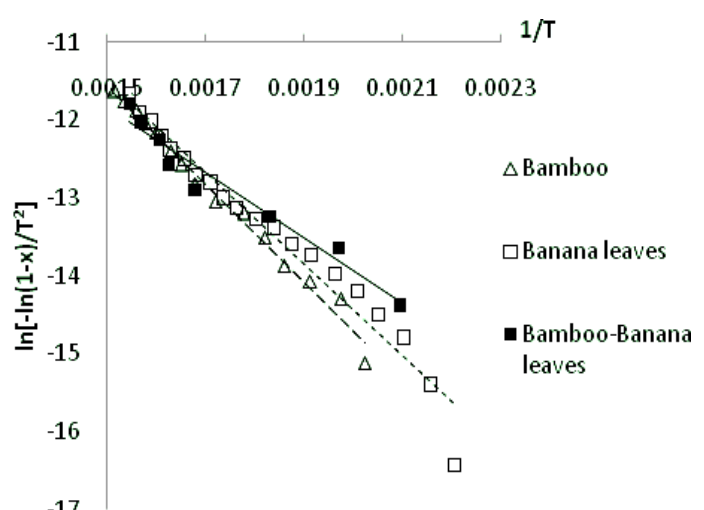

Figure 8. Plot of $\ln \left[-\frac{\ln (1-x)}{T^{2}}\right]$ vs $1 / T$ of banana leaves wastes, bamboo wastes and their blends pyrolysis

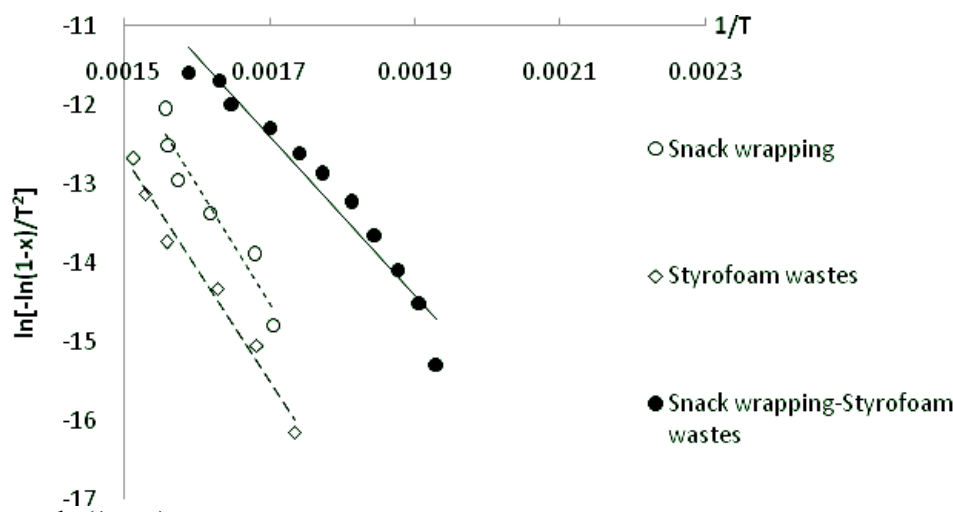

Figure 9. Plot of $\ln \left[-\frac{\ln (1-x)}{T^{2}}\right]$ vs 1/T of Snack wrap wastes, styrofoam wastes and their blends pyrolysis 


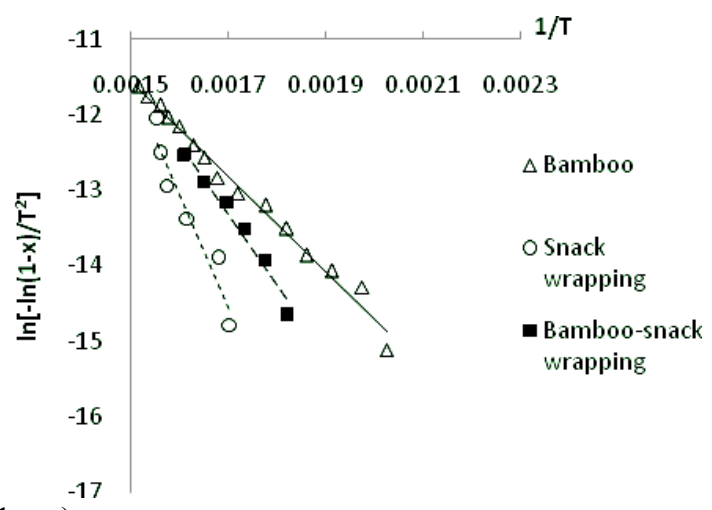

Figure 10. Plot of $\ln \left[-\frac{\ln (1-x)^{-17}}{T^{2}}\right]$ vs $1 / T$ of bamboo wastes, snack wrap wastes and their blends pyrolysis

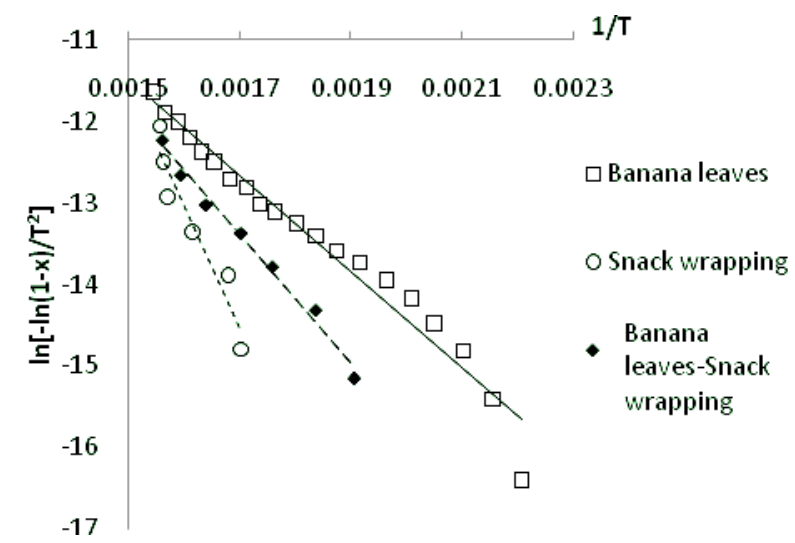

Figure 11. Plot of $\ln \left[-\frac{\ln (1-x)}{T^{2}}\right]$ vs $1 / T$ of banana leaves wastes, snack wrap wastes and their blends pyrolysis

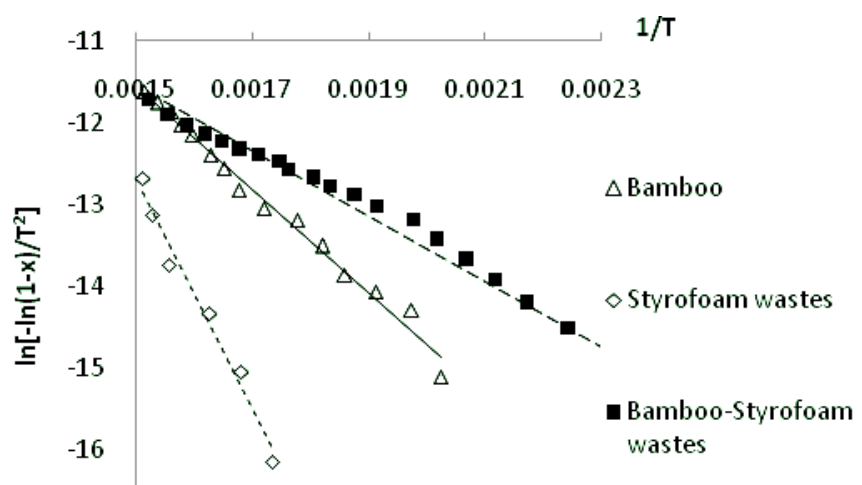

Figure 12. Plot of $\ln \left[-\frac{\ln (1-x)}{T^{2}}\right]$ vs $1 / T$ of bamboo wastes, styrofoam wastes and their blends pyrolysis 


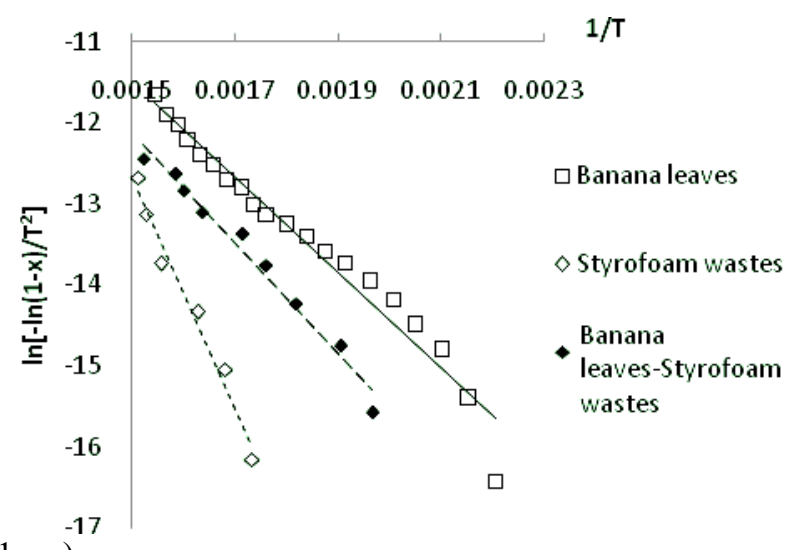

Figure 13. Plot of $\ln \left[-\frac{\ln (1-x)^{-17}}{T^{2}}\right]$ vs $1 / T$ of Banana leaves wastes, styrofoam wastes and their blends pyrolysis 